\title{
OCCURRENCE AND SPATIAL DISTRIBUTION OF HEPATITIS C IN A WESTERN BRAZILIAN AMAZON STATE
}

\author{
Gabriel de Deus VIEIRA, Cledson Gonçalves VENTURA and Camila Maciel de SOUSA
}

\begin{abstract}
Context - Hepatitis C causes a major impact on public health due to the high prevalence in the population. Objectives Evaluate the epidemiological data of hepatitis C in the State of Rondônia, Brazil. Methods - Data from hepatitis C were analyzed during the period 2002 to 2012, assigned by the Agency for Sanitary Vigilance of the State of Rondonia. The variables studied were: year of diagnosis, gender, age, associated disease, exposure to risk factors and clinical presentation. Results - Eight hundred fifty-nine cases were reported during the study period. Of this total, $542(63.1 \%)$ cases were male. In relation to age group, the one with the highest number of cases was between $40-59$ years (54\%), followed by $20-39$ years (33.5\%). In relation to sexually transmitted diseases (STDs) association, $1.8 \%$ of patients had HIV and 2.1\% other type of sexually transmitted disease. About exposure to risk factors, $288(28.1 \%)$ individuals were exposed to a surgical procedure. Was also analyzed the clinical form of the disease, $9.9 \%$ are in acute disease and $91.1 \%$ in the chronic phase. Conclusions - In the State of Rondônia, hepatitis C had a mean annual incidence of 5.1 cases $/ 100,000$ inhabitants, similar to the national rate.
\end{abstract}

HEADINGS - Descriptive epidemiology. Hepatitis C. Hepacivirus.

\section{INTRODUCTION}

The Hepatitis $\mathrm{C}$ virus (HCV) is an RNA virus with an estimated size of 30 to $60 \mathrm{~nm}$ of diameter, belonging to the genus Hepacivirus from Flaviviridae family ${ }^{(14)}$. It is estimated that $3 \%$ of the population worldwide is infected with $\mathrm{HCV}$, in other words, about 200 million individuals $^{(20)}$. On the American continent, the prevalence is $1.7 \%$ and Brazil is $1 \%{ }^{(8,27)}$.

The HCV infection has high mortality ${ }^{(3)}$, being a public health problem because it has a high prevalence in the general population, severe comorbidities, the treatment demand high costs and during the terminal phase, the infected individuals progress to chronic stages of the disease, developing cirrhosis and hepatocellular carcinoma ${ }^{(1)}$. The liver disease generated by $\mathrm{HCV}$ is the most common cause of liver transplantation in Brazil, and even after transplantation, can recur and progress to cirrhosis ${ }^{(4,6)}$.

Among the risk groups, users of intravenous illicit drugs, individuals on dialysis or who received blood transfusions before 1992, hemophiliacs and imprisoned are those with the highest risk, because the main route of transmission is through contaminated blood $^{(8)}$. If it is not treated, HCV infection persists for all life of the infected person, been a mean of spreading the virus ${ }^{(10)}$.
In 2002, the Ministry of Health created the National Program of Viral Hepatitis, whose purpose is to act in the prevention, surveillance and care actions in this area. In Brazil, it is estimated that about 3 million people are carriers of $\mathrm{HCV}$, largely located in the northern region, which has difficulties in implementing social programs and health, further worsening the situation. The Brazilian government in 2004, has spent U\$136,358.05 with preventive measures and treatment of hepatitis C, but only $5 \%$ of this amount was directed to the Amazon region ${ }^{(18)}$

The state of Rondônia is located in a high endemic region of the disease ${ }^{(16)}$. A study in rural areas of Rondônia, showed a prevalence of up to $67.9 \%$ for anti-HBc total antibodies ${ }^{(15)}$. In view of this, this study aims to evaluate the epidemiological data of Hepatitis $\mathrm{C}$ in the state of Rondônia.

\section{METHODS}

This is an epidemiological descriptive study of cases of hepatitis $\mathrm{C}$ diagnosed in the state of Rondônia population during the period 2002-2012. Data and statistics officially assigned by State Agency of Sanitary Surveillance of Rondonia (AGEVISA/RO) were used, through the Information Systems of Notification

Declared conflict of interest of all authors: none

Research performed at: Departamento de Medicina, Faculdade São Lucas, Porto Velho, RO, Brasil.

Departamento de Medicina, Faculdade São Lucas, Porto Velho, RO, Brasil.

Correspondence: Gabriel de Deus Vieira. Departamento de Medicina, Faculdade São Lucas, Rua Alexandre Guimarães, 1927, Areal, CEP: 76804-373 - Porto Velho, RO, Brasil. E-mail: gabrielvieira.mg@hotmail.com 
SINAN NET and SINAN W, in order to provide a better analysis of epidemiological data on the disease. To create the prevalence map, the program TABWIN (www.datasus. gov.br/tabwin) was used. The variables studied were: year of diagnosis, gender, age, associated disease, exposure to risk factors and clinical presentation.

\section{RESULTS}

Were reported 859 cases of hepatitis $\mathrm{C}$ during the studied period, with an average prevalence of 77.4 cases/year and average annual incidence of 5.1 cases per 100,000 population (Figure 1). Of this total, 542 cases $(63.1 \%$ ) were male and 317 $(36.9 \%)$ female. Twenty-nine $(1.3 \%)$ women were pregnant. In relation to known contact with carrier of HCV, $28(3.2 \%)$ of patients had sexual contact and $25(3.1 \%)$ had intimate household contact. As for the age variable, the one with the highest number of cases was between $40-59$ years $(54.3 \%)$. On exposure to risk factors, $288(28.1 \%)$ individuals were exposed to any surgical procedure and $142(13.8 \%)$ individuals were exposed to three or more partners (Table 1). In relation to sexually transmitted diseases (STD) associated, $1.8 \%$ of patients had HIV and $2.1 \%$ other type of STD. On the clinical form of the disease, $9.9 \%$ are in acute disease phase and $91.1 \%$ in the chronic.

The municipalities that had the highest number of cases were Porto Velho $(\mathrm{n}=475)$, Ariquemes $(\mathrm{n}=94)$, Ji-Paraná $(\mathrm{n}=60)$, Vilhena $(\mathrm{n}=55)$ and Cacoal $(\mathrm{n}=55)($ Figure 2$)$.

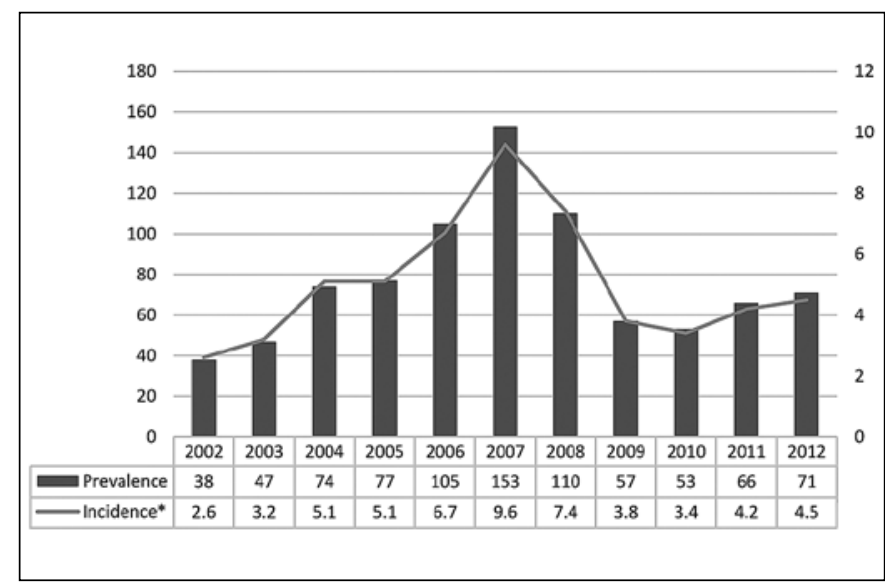

FIGURE 1. Prevalence and annual incidence of cases of hepatitis $C$ diagnoses in the state of Rondônia during the period 2002-2012. Source: SINAN W and SINAN NET. * Calculation based on 100,000 inhabitants.

\section{DISCUSSION}

The state of Rondônia is located in a region with high endemicity of hepatitis C. In this study, was observed a similar incidence with theBrasilian rates, ranging from 5 to 5.4 cases per 100,000 population between the years $2006-2010^{(17)}$. Was also noted, the internalization of the disease, affecting several municipalities in the state. According Lobalo et al. ${ }^{(16)}$, this
TABLE 1 . Social and clinical data of patients with hepatitis C in Rondônia during the period 2002-2012

\begin{tabular}{|c|c|c|c|}
\hline Variables & $\mathbf{N}^{\circ}$ & $\%$ & Ignored* \\
\hline Age group & & & 0 \\
\hline $0-09$ & 13 & 1.6 & \\
\hline $10-19$ & 34 & 3.9 & \\
\hline $20-39$ & 288 & 33.6 & \\
\hline $40-59$ & 467 & 54.3 & \\
\hline$>60$ & 57 & 6.6 & \\
\hline Contact with a patient with $\mathrm{HCV}$ & & & 0 \\
\hline Sexual contact & 28 & 3.2 & \\
\hline Intimate household contact & 25 & 3.1 & \\
\hline Exposure to risk factors & & & 0 \\
\hline Surgical procedure & 288 & 28.1 & \\
\hline Three or more partners & 142 & 13.8 & \\
\hline Blood transfusion & 133 & 12.9 & \\
\hline Use of Injecting medication & 103 & 10.1 & \\
\hline Tattoo / Piercing & 71 & 6.9 & \\
\hline Inhaled drugs & 65 & 6.3 & \\
\hline Use of illicit intravenous drug & 52 & 5.1 & \\
\hline Acupuncture & 21 & 2.1 & \\
\hline Hemodialysis & 11 & 1.2 & \\
\hline Accident at work & 9 & 0.8 & \\
\hline Transplant & 1 & 0.1 & \\
\hline Clinic form & & & 314 \\
\hline Acute & 52 & 9.9 & \\
\hline Cronic & 493 & 91.1 & \\
\hline
\end{tabular}

* Absence of data in the system, due to not completing the notification form. Source: SINAN W and SINAN NET.

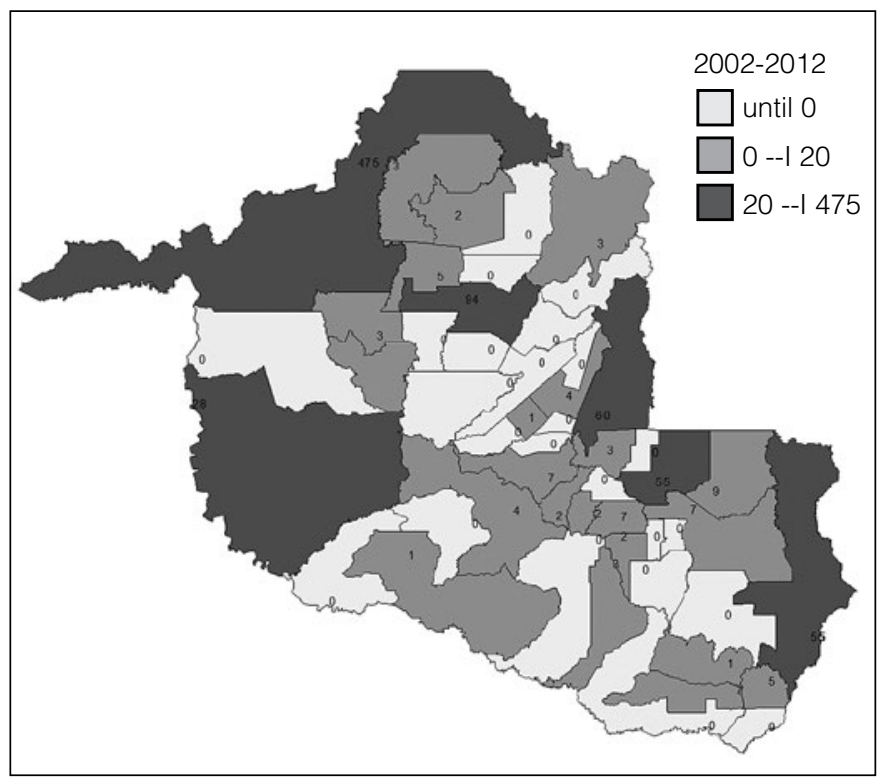

FIGURE 2. Prevalence of cases diagnosed with hepatitis C in Rondônia during the period 2002-2012. Source: SINAN W and SINAN NET. 
can be explained due to failure in social programs and from public health control as prenatal, control of blood transfused and the habits of the population, such as promiscuity and the habit of sharing utensil personal use. In this study it was shown that $3.1 \%$ of the infected individuals had some known intimate household contact with a person infected by the virus.

In this study, shows a predominance of males over females. Vasconcelos et al. ${ }^{(24)}$ in their study, found that $56.3 \%$ of individuals with hepatitis $C$ were males and $43.7 \%$ females. Aquino et al ${ }^{(2)}$ in their study on hepatitis $\mathrm{C}$ in Pará, also found higher prevalence in males. The prevalence of hepatitis $\mathrm{C}$ virus was $3.6 \%$ in the study population and there was a predominant among individuals above 50 years. In this study, the age group with the highest prevalence was between 40-59 years $(54.3 \%)$. Vertical transmission of $\mathrm{HCV}$ can reach up to $25 \%$ of pregnancies with infected mothers, and that value can increase if the pregnant woman is in viral replication during labor ${ }^{(19)}$. The presence of $3.3 \%$ of pregnant women was noted in this study. According Gardenal et al. ${ }^{(12)}$ in his study of prevalence of HCV infection in pregnant women during prenatal, noted that $0.2 \%$ of pregnant women were infected. According to the authors, some factors are associated with the increased vertical transmission of the virus, such as blood transfusion, tattoo, intravenous drug use and the presence of multiple partners, and many of partners were drug users or had done blood transfusion.

$\mathrm{HCV}$ is the cause of $90 \%$ of post-transfusion hepatitis. All the people who received blood before age 90 should be examined and conducted laboratory tests for hepatitis C. Currently, the post-transfusion hepatitis is rare, but other means of transmission by contact with contaminated blood can propagate $\mathrm{HCV}$, as syringes and/or contaminated needles and inhalation of drugs with the use of pipes and contaminated mirrors ${ }^{(23)}$.

In this study it was noted that $12.9 \%$ of individuals were exposed to blood transfusion, $6.3 \%$ for inhaled drugs, $5.1 \%$ for injecting illicit drugs and $1.2 \%$ for hemodialysis. In a study conducted among blood donors in Uberaba-MG by Garcia et al. ${ }^{(11)}$, the authors found that $0.3 \%$ of donors had the presence of anti-HCV. According to the authors, this was due to increased drug use and the reduction of transmission by transfusion mode due to serological screening tests. According to Fonseca et al. ${ }^{(9)}$ in a study conducted in the northern region of the country, was shown the prevalence of $2.1 \%$ among candidates for blood donation.

In this study were evidenced the presence of co-infection with human immunodeficiency virus (HIV) in $1.8 \%$ of cases. This occurs because both diseases present almost the same transmission routes. In the United States and Europe, it is estimated that $30 \%$ of HIV patients are also infected with $\mathrm{HCV}$, this association is greater when these individuals contract HIV by parenterally mode ${ }^{(22)}$. In co-infected patients, the aggression and progression of $\mathrm{HCV}$ infection is higher and have a high viral replication, with further development of liver cirrhosis and hepatocellular carcinoma ${ }^{(7)}$. Carvalho et al. ${ }^{(5)}$ in a study with $343 \mathrm{HIV}$ patients, showed that the prevalence of co-infection based on the detection of anti-HCV was $4.1 \%(n=14)$ and $3.2 \%(n=11)$ when used in the RT-PCR. In Rondônia, this association may be even higher, because studies on the epidemiology of HIV/AIDS in the state show that the disease is on the rise ${ }^{(25,26)}$.

In this study it was noted that $91.1 \%$ of the infected individuals are in the chronic phase of the disease. This is worrisome because there is high chance of these individuals evolve to cirrhosis or hepatocellular carcinoma, may be indicated for liver transplantation in most cases ${ }^{(13)}$. According to Rodriguez-Luna et al. ${ }^{(21)}$, HCV recurrence after transplantation occurs almost in all patients and the evolution of the disease in transplant patients is much faster and more aggressive than in non-transplanted patients. Vasconcelos et al. ${ }^{(24)}$ in their study on risk factors in the chronic phase of hepatitis $\mathrm{C}$ with 426 patients, found that the most common risk factor for the development of the disease were blood transfusion followed by the use of inhaled drugs. According to the authors, there was an association between over 40 years at the time of liver biopsy, serum albumin levels below the lower limit of normal, the platelet number less than 150.000 $\mathrm{mm}^{3}$, necro-inflammatory activity and fibrosis level with the chronicity of the disease.

Katsuragawa et al. ${ }^{(15)}$ in their study on the serum prevalence of anti-HCV in the riverine population of Rondonnia, found that $7.4 \%$ of the population tested were reagent. According to the authors, the high rate of $\mathrm{HCV}$ infection occurs due to migration processes occurred in the $70 \mathrm{~s}$ and $80 \mathrm{~s}$ and due the local habits of sharing personal objects.

\section{CONCLUSION}

The state of Rondônia is situated in a region with the highest rates of infection with the hepatitis $\mathrm{C}$ virus in Brazil, which is the Amazon region, with average annual incidence of 5.1 cases per 100,000 population, but it is believed that this rate may be even higher due to sub-notification cases. Control and public education measures are necessary, in order to awareness the population about the modes of transmission and means of diagnosis and treatment of the disease. 
Vieira GD, Ventura CG, Sousa CM. Ocorrência e distribuição espacial da hepatite C em Estado da Amazônia Ocidental Brasileira. Arq Gastroenterol. 2014,51(4):316-9.

RESUMO - Contexto - A hepatite C causa um grande impacto na saúde pública, devido à alta prevalência na população. Objetivos - Avaliar os dados epidemiológicos da hepatite C no Estado de Rondônia, Brasil. Métodos - Foram analisados os dados da hepatite C durante o período 2002 a 2012 , cedidos pela Agência de Vigilância Sanitária do Estado de Rondônia. As variáveis estudadas foram: ano de diagnóstico, gênero, faixa etária, agravo associado, exposição a fatores de risco e forma clínica. Resultados - Foram notificados 859 casos durante o período analisado. Desse total, 542 (63,1\%) casos são do gênero masculino. Em relação à faixa etária, a que obteve o maior número de casos foi entre 40-59 anos (54\%), seguida de 20-39 anos $(33,5 \%)$. Em relação às doenças sexualmente transmissíveis associadas, $1,8 \%$ dos pacientes tinham HIV e 2,1\% outro tipo de doença sexualmente transmissível. Sobre exposição a fatores de risco, 288 (28,1\%) indivíduos foram expostos a algum procedimento cirúrgico. Também foi analisada a forma clínica da doença, sendo que $9,9 \%$ estão na aguda da doença e $91,1 \%$ na fase crônica. Conclusões - No Estado de Rondônia, a hepatite C teve incidência média anual de 5,1 casos/100.000 habitantes, semelhante à taxa nacional.

DESCRITORES - Epidemiologia descritiva. Hepatite C. Hepacivirus.

\section{REFERENCES}

1. Alter MJ. Epidemiology of viral hepatitis C infection. World J Gastroenterol. 2007;13:2436-41

2. Aquino JA, Pegado KA, Barros LP, Machado LFA. [Seroprevalence of hepatitis $B$ virus and hepatitis $C$ virus infections among individuals in the State of Pará]. Rev Soc Bras Med Trop. 2008;41:334-7.

3. Araújo AR, Almeida CM, Fraporti L, Garcia N, Lima TA, Maia LPV, et al. [Characterization of hepatitis $\mathrm{C}$ virus in chronic hepatitis patients: genotypes in the State of Amazonas, Brazil]. Rev Soc Bras Med Trop. 2011;44:638-40.

4. Bittencourt PL, Silva RCSMA, Pessoa MG, Marroni CA. National survey about management and treatment options of hepatitis $\mathrm{C}$ recurrence after liver transplantation. Arq Gastroenterol. 2007;44:78-84.

5. Carvalho FHP, Coêlho MRCD, Vilel TAS, Silva JLA, Melo HRL. Co-infecção por HIV/HCV em hospital universitário de Recife Brasil. Rev Saúde Pública. 2009;43:133-9.

6. Coelho JCU, Freitas ACT, Matias JEF, Zeni-Neto C, de Godoy JL, Parolin MB, Okawa L. Donor complications including the report of one death in right-lobe living donor liver transplantation. Dig Surg. 2007:24:191-6.

7. Darby SC, Ewart DW, Giangrande PL, Spooner RJ, Rizza CR, Dusheiko GM, et al. Mortality from liver cancer and liver disease in hemophiliac men and boys in UK given blood products contaminated with hepatitis C. Lancet. 1997;350:1425-31

8. Ferreira CT, Silveira TR. Viral Hepatitis: epidemiological and preventive aspects. Rev Bras Epidemiol. 2004;7:473-87.

9. Fonseca JC. Epidemiologia da infecção pelo vírus da hepatite C no Brasil Relatório do Grupo de Estudo da Sociedade Brasileira de Hepatologia. Gastrenterol Endosc Digest. 1999;18:S3-8.

10. Gale Jr M, Foy EM. Evasion of intracellular host defence by hepatitis $\mathrm{C}$ virus. Nature 2005;436:939-45.

11. Garcia FB, Pereira GA, Martins PRJ, Moraes-Souza H. Perfil epidemiológico para hepatite $\mathrm{C}$ em doadores de sangue do hemocentro regional de Uberaba. Rev Soc Bras Med Trop. 2009;42:1-4.

12. Gardenal RVC, Figueiró-Filho EA, Luft JL, Paula GLSA, Vidal FG, Turine Neto $P$, Souza RAA. Hepatite C e gestação: análise de fatores associados à transmissão vertical. Rev Soc Bras Med Trop. 2011;44:43-7.

13. Guo L, Orrego M, Rodriguez-Luna H, Balan V, Byrne T, Chopra K, et al. Living donor liver transplantation for hepatitis C-related cirrhosis: no difference in histological recurrence when compared to deceased donor liver transplantation recipients. Liver Transpl. 2006;12:560-5.
14. Houghton M, Weiner A, Han J, Kuo G, Choo QL. Molecular biology of the hepatitis $\mathrm{C}$ viruses: implications for diagnosis, development and control of viral disease. Hepatology. 1991;14:381-8.

15. Katsuragawa TH, Cunha ROA, Salcedo JMV, Souza DACA, Gil LHS, et al. Alta soroprevalência dos marcadores das hepatites $\mathrm{B}$ e $\mathrm{C}$ na região do alto rio Madeira, Porto Velho, Rondônia, Brasil. Rev Pan-Amaz Saude. 2010;1:91-6.

16. Lobato C, Tavares-Neto J, Rios-Leite M, Trepo C, Vityitski L, Parvaz P, et al. Intrafamilial prevalence of hepatitis B virus in Western Brazilian Amazon region: epidemiologic and biomolecular study. J Gastroenterol Hepatol. 2006;21: 863-8.

17. Ministério da Saúde. Secretaria de Vigilância em Saúde. Departamento de DST, Aids e Hepatites Virais. Boletim Epidemiológico: hepatites Virais. Brasília: Ministério da Saúde, 2012.

18. Paraná R, Vitvitski L, Pereira JE. Hepatotropic Viruses in the Brazilian Amazon: A Health Threat. Braz J Infect Dis. 2008;12:253-6.

19. Parthiban R, Shanmugam S, Velu V, Nandakumar S, Dhevahi E, Thangaraj K, et al. Transmission of hepatitis $\mathrm{C}$ virus infection from asymptomatic mother to child in southern India. Int J Infect Dis. 2009;13:394-400.

20. Pavio N, Lai MMC. The hepatitis C virus persistence: how to evade the immune system? J Biosci. 2003;28:287-304.

21. Rodrigues-Luna H, Vargas HE, Sharma P, Ortiz J, de Petris G, Balan V, et al. Hepatitis $C$ virus recurrence in living donor liver transplant recipients. Dig Dis Sci. 2004;49:38-41.

22. Soriano V, Sulkowski M, Bergin C, Hatzakis A, Cacoub P, Katlama C, et al. Care of patients with chronic hepatitis $\mathrm{C}$ and HIV coinfection: recommendations from the HIV-HCV International Panel. AIDS. 2002;16:813-28.

23. Strauss E. Hepatite C. Rev Soc Bras Med Trop. 2001;34:69-82.

24. Vasconcelos RR, Tengan, FM, Cavalheiro NP, Ibrahim K, Pereira H, Barone AA. [Factors associated with severe evolutive forms of chronic infection with hepatitis C virus]. Rev Soc Bras Med Trop. 2006; 39:433-8.

25. Vieira GD, Alves TC, Sousa CM. Perfil da Aids em indivíduos acima de 50 anos na região amazônica. Rev Bras Geriatr Gerontol. 2014;17:75-80.

26. Vieira GD, Alves TC, Sousa CM. Epidemiological evolution of vertical HIV transmission in Rondônia, Brazil. Braz J Infect Dis. 2013;17:613-4.

27. Wong T, Lee SS. Hepatitis C: a review for primary care physicians. CMAJ 2006;174:649-59. 